University of Nebraska - Lincoln

DigitalCommons@University of Nebraska - Lincoln

Faculty Publications: Department of

Entomology

Entomology, Department of

2019

The Genera of Agaocephalini (Coleoptera: Scarabaeidae:

Dynastinae) of Colombia, with Description of a New Species of Lycomedes Breme

\author{
Jhon César Neita-Moreno \\ Instituto de Investigaciones de Recursos Biológicos Alexander von Humboldt, jneita@humboldt.org.co \\ Brett C. Ratcliffe \\ University of Nebraska-Lincoln, bratcliffe1@unl.edu
}

Follow this and additional works at: https://digitalcommons.unl.edu/entomologyfacpub

Part of the Entomology Commons

Neita-Moreno, Jhon César and Ratcliffe, Brett C., "The Genera of Agaocephalini (Coleoptera:

Scarabaeidae: Dynastinae) of Colombia, with Description of a New Species of Lycomedes Breme" (2019).

Faculty Publications: Department of Entomology. 815.

https://digitalcommons.unl.edu/entomologyfacpub/815

This Article is brought to you for free and open access by the Entomology, Department of at DigitalCommons@University of Nebraska - Lincoln. It has been accepted for inclusion in Faculty Publications: Department of Entomology by an authorized administrator of DigitalCommons@University of Nebraska - Lincoln. 


\title{
The Genera of Agaocephalini (Coleoptera: Scarabaeidae: Dynastinae) of Colombia, with Description of a New Species of Lycomedes Brême
}

\author{
Jhon C. Neita-Moreno \\ Instituto de Investigaciones de Recursos Biológicos Alexander von Humboldt \\ Claustro de San Agustín, Villa de Leyva, Boyacá, COLOMBIA \\ jneita@humboldt.org.co \\ AND \\ Brett C. RatclifFe \\ Systematics Research Collections, W-436 Nebraska Hall \\ University of Nebraska State Museum \\ Lincoln, NE 68588-0514, USA \\ bratcliffe1@unl.edu
}

\begin{abstract}
The six genera of Agaocephalini in Colombia are distinguished in a dichotomous key and illustrated. Lycomedes enigmaticus Neita-Moreno and Ratcliffe, new species, is described and differentiated by character comparisons with other previously known Colombian species. Lycomedes lydiae Arnaud, 2012 is proposed as a new junior synonym of Lycomedes reichei Brême, 1844.

\section{RESUMEN}

Los seis géneros de Agaocephalini en Colombia son incluidos e ilustrados en una clave dicotómica. Se describe Lycomedes enigmaticus Neita-Moreno y Ratcliffe, especie nueva y es diferenciada por comparación de caracteres con otras especies previamente conocidas de Colombia. Se propone Lycomedes lydiae Arnaud, 2012 como un nuevo sinónimo junior de Lycomedes reichei Brême, 1844.
\end{abstract}

Key Words: scarab beetles, taxonomy, nomenclature, identification key, Neotropical

DOI.org/10.1649/0010-065X-73.4.1049

Zoobank.org/urn:lsid:zoobank.org:pub:49980652-3487-4895-A996-6ED95E66FA8D

The tribe Agaocephalini includes 11 genera and 46 species (Endrödi 1970, 1985; Krajcik 2005; Neita-Moreno 2015; Pardo-Locarno et al. 2015; Milani 2017) distributed in Central and South America, with one species in the West Indies (Ratcliffe and Cave 2015). The greatest diversity of the group occurs in South America, where there are 11 genera and $88 \%$ of the species.

The Agaocephalini are difficult to characterize due to the high degree of variability of characters among several genera (Ratcliffe 2003). Adults are medium size, suboval in form, slightly dorsoventrally flattened and have a propygidium lacking a stridulatory area and slender meso- and metatarsomeres (Ratcliffe 2003). They are similar to members of Dynastini but have irregular punctures on the elytra (never with punctate striae). Some immature stages were recently described for Aegopsis Burmeister (Fig. 1F-H) and Lycomedes Brême (Pardo-Locarno and Morón 2006; NeitaMoreno et al. 2014). Little is known about the natural history of the species except that adults are attracted to lights and occur in pristine forest habitats. Species of Aegopsis, however, have adapted to agricultural environments: Aegopsis curvicornis Burmeister breeds in soils high in organic matter, and Aegopsis bolboceridus (Thomson) feeds on the roots of crops in Brazil (Oliveira et al. 2008).

Six genera and 14 species of Agaocephalini occur in Colombia (Endrödi 1985; Restrepo-Giraldo et al. 2003; Neita-Moreno and Gaigl 2008; GascaÁlvarez and Amat-García 2010; Milani 2017). They are Aegopsis (one species), Brachysiderus Waterhouse (one species), Horridocalia Endrödi (one species), Lycomedes (six species), Mitracephala Thomson (one species), and Spodistes Burmeister (four species). Lycomedes currently contains 10 species (Pardo-Locarno et al. 2015; Milani 2017) distributed in Colombia, Ecuador, and Peru; six species occur in Colombia. We describe here one new species, and a new synonymy is proposed.

\section{Material And Methods}

Internal and external morphological characters were studied using a dissecting microscope (6.5-40.0X). For measurements, an ocular micrometer was used. Internal sclerotized structures 

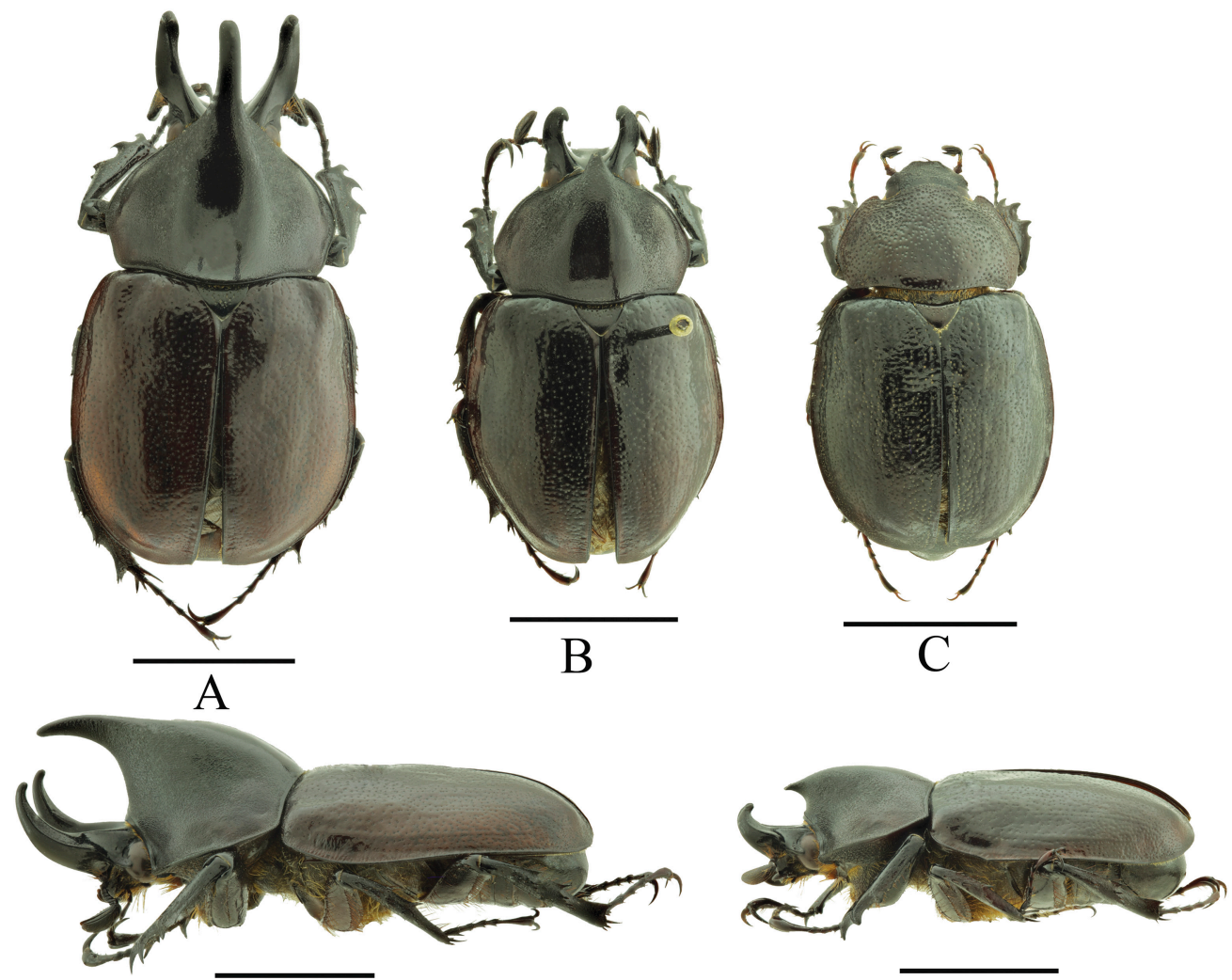

D
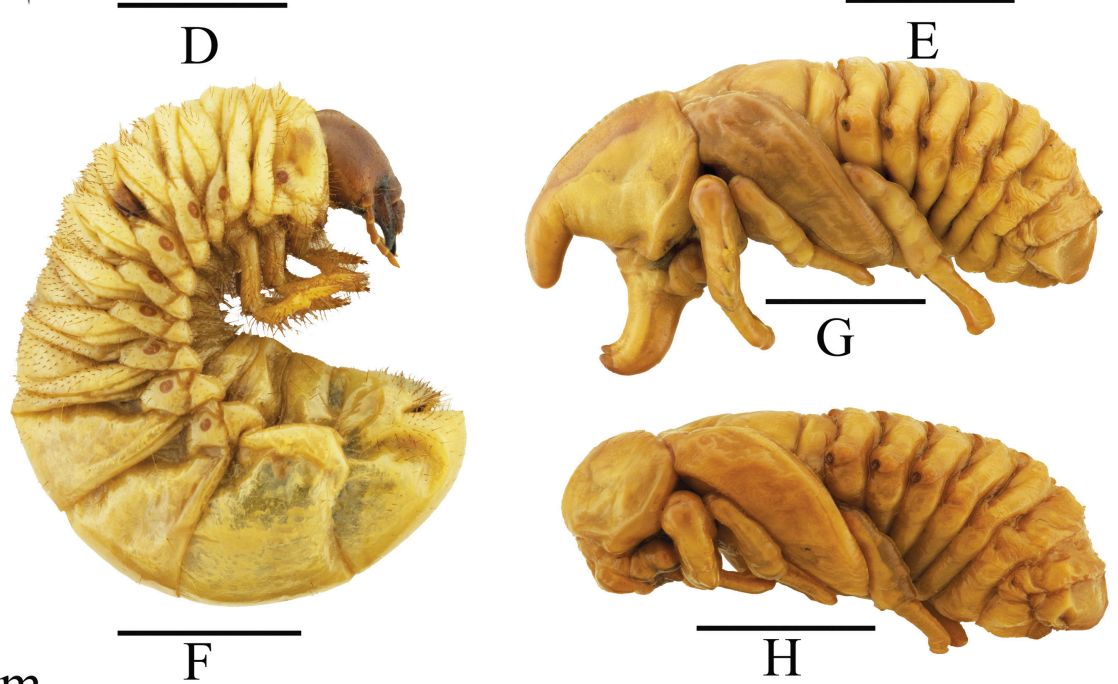

\section{$10 \mathrm{~mm}$}

Fig. 1. Aegopsis curvicornis. A, D) Male major, B, E) Male minor, C) Female, F) Third instar, G) Male pupa, H) Female pupa.

were dissected after relaxing the specimen in hot $\left(75^{\circ} \mathrm{C}\right)$ water. Heavily sclerotized parts were soaked in a $15 \%$ solution of potassium hydroxide and neutralized in a $15 \%$ solution of acetic acid. Genitalia were card-mounted or placed in a glycerin-filled vial beneath the specimen.

The following morphological variables were used for characters: 
Body length: The length is measured from the apex of the clypeus to the apex of the elytra.

Puncture density: Punctures are defined as dense if punctures are nearly confluent to less than two puncture diameters apart; moderately dense if punctures are between 2-6 puncture diameters apart; and sparse if punctures are separated by more than six puncture diameters.

Setae: Setae are "hair-like" if slender and erect; "thickened" if slightly thickened and erect or partially decumbent; and "spine-like" if stout and short. Setae are subject to wear and may be abraded.

Color: Color is based on dry specimens viewed with magnification and illumination. Nearly all species are black or piceous, while some are dark reddish brown.

Material Examined. The results of this study were based on 85 specimens from the following institutions and collections:

ANDES Colección de Entomología, Universidad de los Andes, Bogotá, DC, Colombia (Oscar Mahecha).

CTNI Colección Taxonómica Nacional de Insectos "Luis Maria Murillo", Corporación Colombiana de Investigación Agropecuaria (Agrosavia), Colombia (Erika Vergara).

IAvH Colecciones Biológicas, Sección de Entomología, Instituto de Investigaciones de Recursos Biológicos Alexander von Humboldt, Villa de Leyva, Boyacá, Colombia (Jhon Neita-Moreno).

ICN- Colección de Zoología, Instituto de

MHN Ciencias Naturales, Universidad Nacional de Colombia, Bogotá, DC, Colombia (German Amat-García).

LGAC Museo de Historia Natural "Luis Gonzalo Andrade", Colección Entomológica, Universidad Pedagógica y Tecnológica de Colombia, Tunja, Boyacá, Colombia (Fredy Molano).

MEFLG Museo Entomológico "Francisco Luis Gallego", Universidad Nacional de Colombia, sede Medellín, Antioquia, Colombia (Jhon Alveiro Quiroz).

MPUJ Museo Javeriano de Historia Natura "Lorenzo Uribe", Pontificia Universidad Javeriana, Bogotá, DC, Colombia (Dimitri Forero).

MUAC Colección de Ciencias Naturales, Universidad de Antioquia, Medellín, Antioquia, Colombia (Marta Wolf).

UNAB Museo Entomológico, Facultad de Agronomía, Universidad Nacional de Colombia, Bogotá, DC, Colombia (Francisco Serna y Erika Vergara).
The distribution map was georeferenced according to specimen label data and then converted into point polygon layers in ArcMap 10.2 (Environmental Systems Research Institute 2013).

\section{Results}

\section{Key to the Genera of Adult Agaocephalini} FROM COLOMBIA

1. Surface glabrous, weakly shiny (Figs. 1A-E, 2A-B, 3A-C) ................... 2

$1^{\prime}$. Surface completely covered with grayish brown tomentum (Figs. 2C-E, 3D-F, 8A-C, $9 \mathrm{~A}-\mathrm{C}, 11 \mathrm{~A}-\mathrm{D})$..................... 4

2. Protibia quadridentate (Fig. $1 \mathrm{~A}-\mathrm{C})$. Mandibles without external teeth (Fig. 4A-B); galea shorted (Fig. 5A)

Aegopsis Burmeister

2'. Protibia tridentate (Figs. 2A-B, 3A-B). Mandibles with 2 external teeth (Figs. 4C-D); galea elongated (Fig. 5B, D) ................ 3

3. Prosternal process developed, apex flattened (Fig. 6B-C) .......... Mitracephala Thomson

3'. Prosternal process undeveloped (Fig. 6A) ... Brachysiderus Waterhouse

4. Prosternal process undeveloped (Fig. 6D). Apical maxillary palpomere with sensorial area (Fig. 5E-F) .............. Spodistes Burmeister

4'. Prosternal process present (Fig. 6E-F). Apical maxillary palpomere without sensorial area (Fig. 5C) ................... 5

5. Galea without teeth (e.g., Fig. 5D). Metepisternum divided by a line, basal area smooth, lacking setae (Fig. 7D)

Horridocalia Endrödi

5'. Galea with teeth (Fig. 5C). Metepisternum rugopunctate, not divided by a line, basal area with setae (Fig. 7C, E)

Lycomedes Brême

\section{Lycomedes enigmaticus Neita-Moreno and Ratcliffe, new species}

Zoobank.org/urn:lsid:zoobank.org:act: B239AAC3-D894-4237-8BC0-BBAC1F9C344E (Figs. 6E, 8A-C, 9B, D, F, 10E-F)

Type Material. Holotype and allotype labeled "Colombia, Tolima, Anzoátegui. Vda. Esmeralda. Finca Tabio. $4^{\circ} 37^{\prime} 14.34^{\prime \prime} \mathrm{N}$; 7507'18.66' $\mathrm{W}$. 2406 m. 01.i.2000. A. Osorio". The types are deposited at the Museo Laboratorio de Entomología, Universidad del Tolima, Colombia.

Description. Holotype. Male (Fig. 8A, C). Length $=29.0 \mathrm{~mm}$; width across humeri = $14.1 \mathrm{~mm}$. Color grayish brown and tan, finely velutinous, with clypeus and part of horns piceous. 

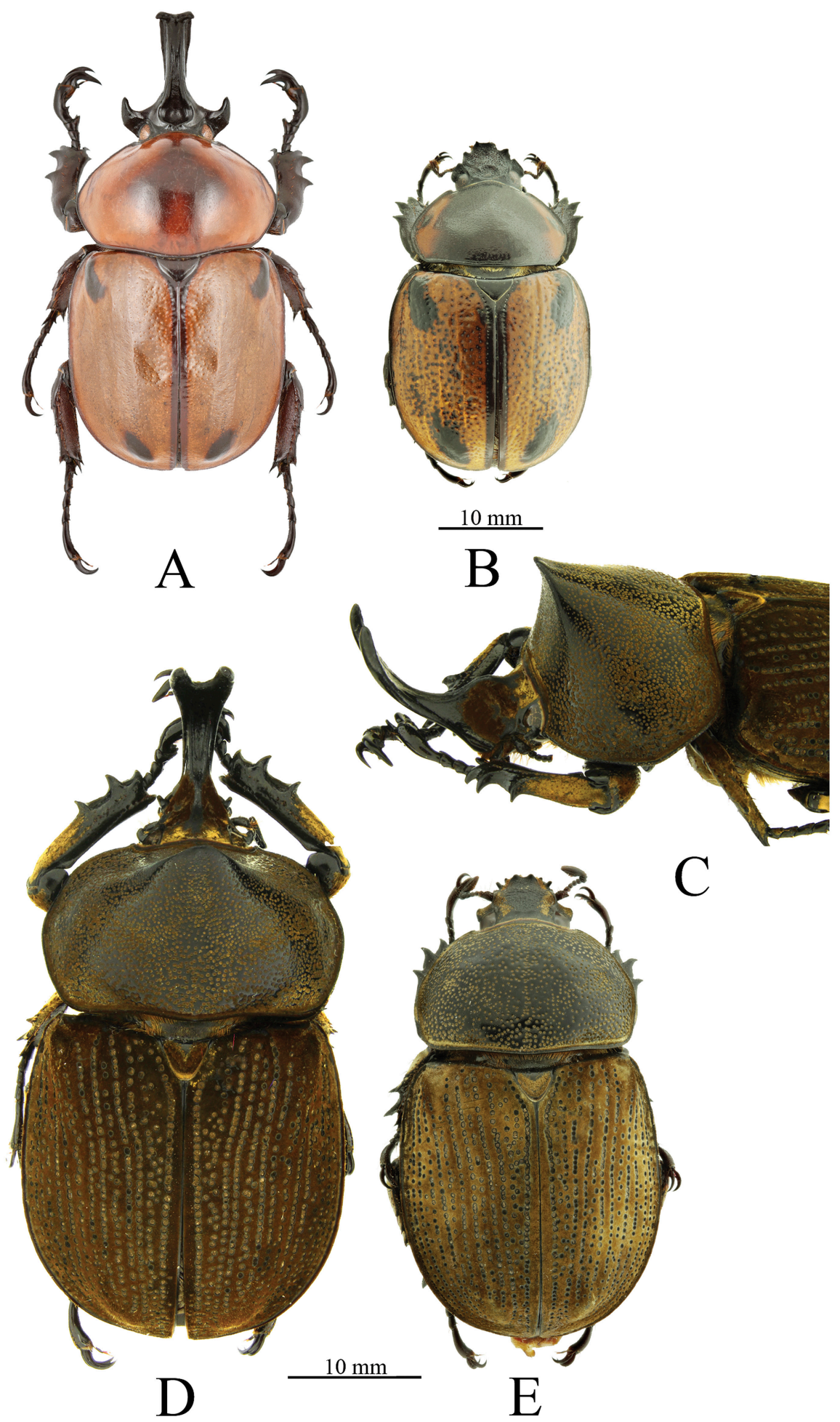

Fig. 2. Brachysiderus quadrimaculatus: A) Male, B) Female. Horridocalia delislei: C-D) Male, E) Female. 


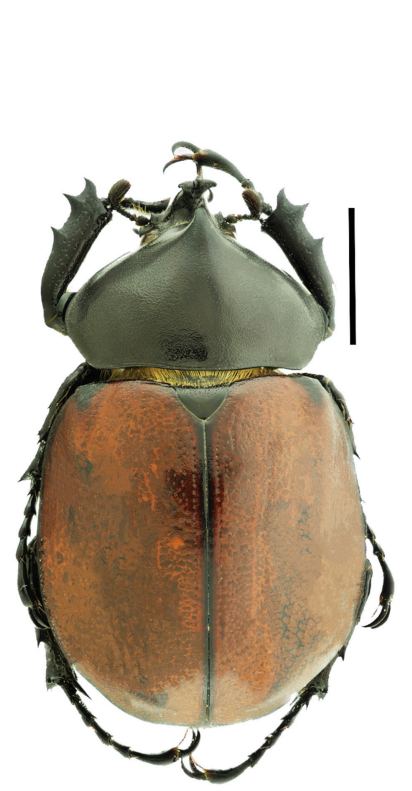

A

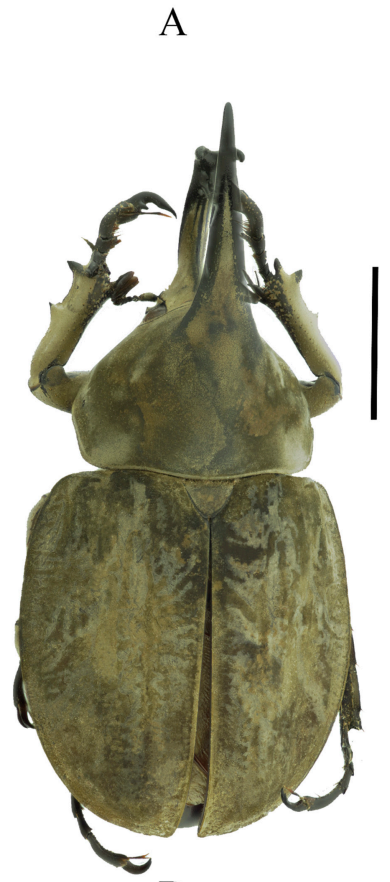

D
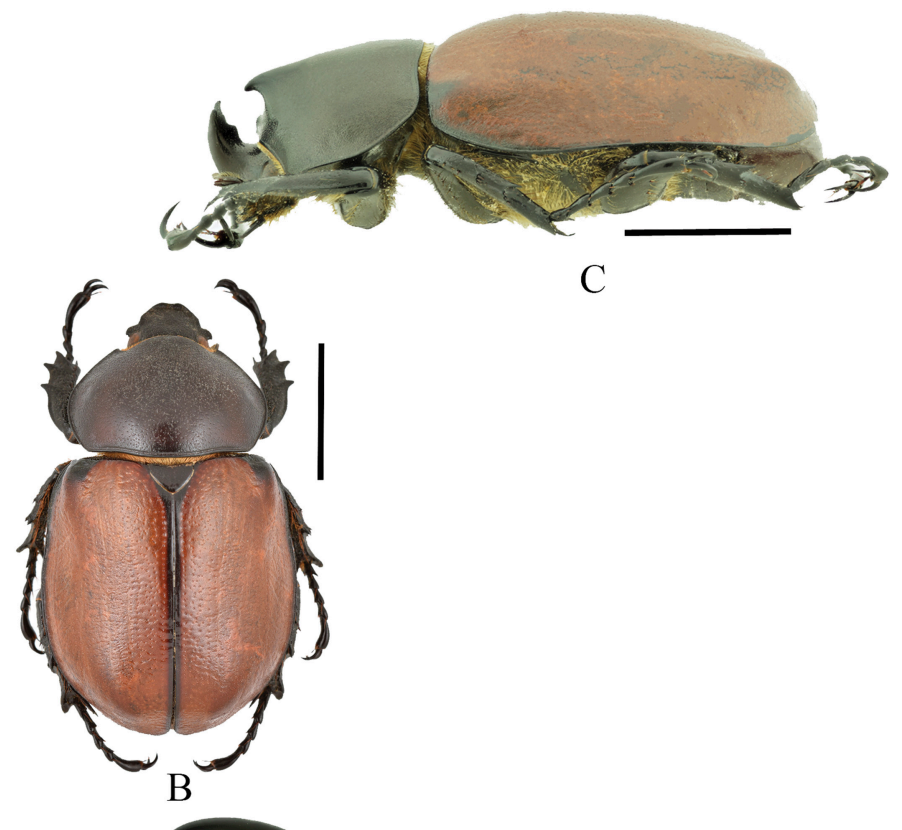

C
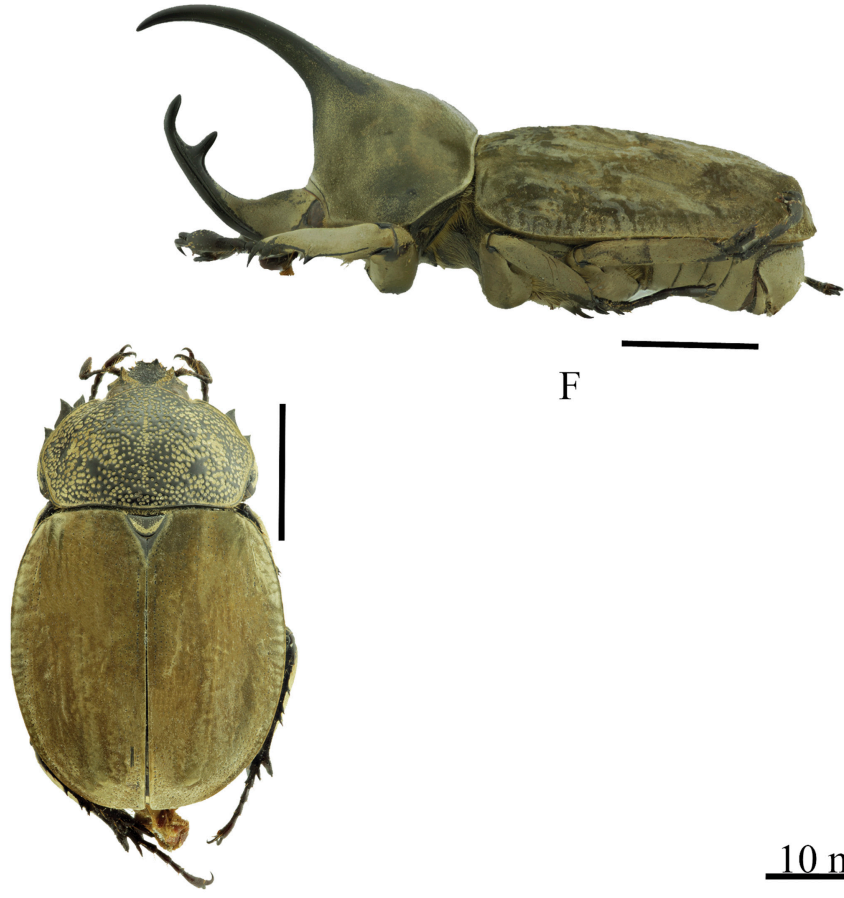

F

Fig. 3. Mitracephala humboldtii: A) Male, (B) Female, C) Male, lateral view. Spodistes hopei: D) Male, (E) Female, (F) Male, lateral view.

Head: Frons with short, erect, slightly recurving horn; apex strongly bifurcate; horn subtriangular in cross-section, apex strongly bifurcate. Ocular canthus acute on apico-lateral corner. Clypeal apex blunt, continuous with anterior face of horn. Interocular width equals 3.0 transverse eyes diameters. Antenna with 10 antennomeres, club slightly shorter than antennomeres 2-7. Mandibles 

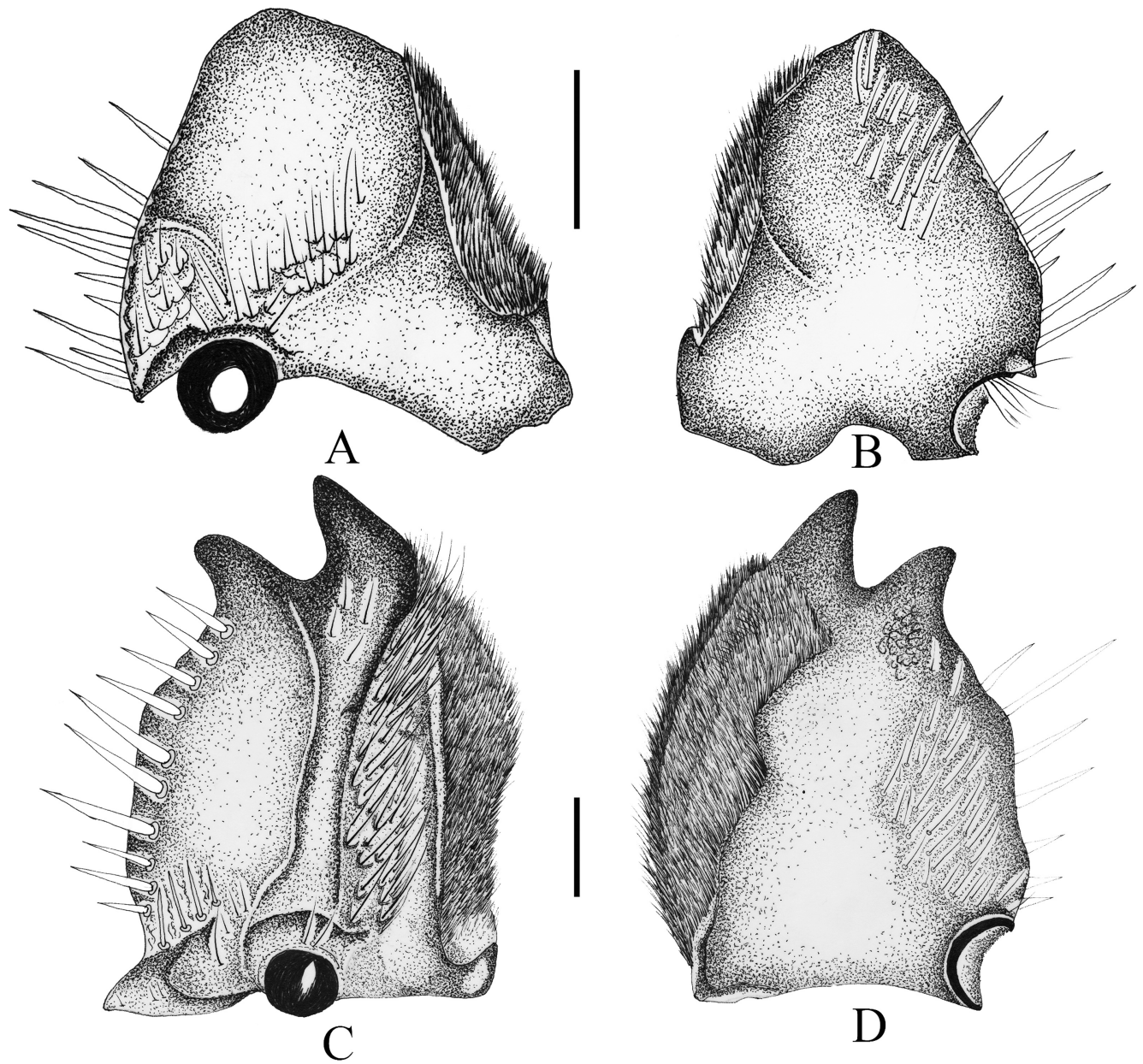

Fig. 4. Mandibles, dorsal and ventral views, respectively. A-B) Aegopsis curvicornis, C-D) Brachysiderus quadrimaculatus.

strongly bidentate, mostly hidden beneath fringe of setae below apex of clypeus. Pronotum: Center of disc with short, erect horn; apex not dilated. Surface with minute, pale, moderately dense, setigerous punctures. Lateral margins widest behind middle. Base with complete marginal bead. Elytra: Surface with moderately dense, small, setigerous punctures (most in rows) on velutinous covering; setae minute, pale. Sides explanate, apical umbones prominent (Fig. 8C). Pygidium: Surface with short, dense, pale setae. Surface convex in lateral view. Legs: Protibia tridentate, basal tooth removed from others. Protarsus enlarged, median claw smooth, without tooth. Apex of metatibia truncate with strong, median angle with single, small spinule. Apex of metatarsomere 1 spiniform, extending to middle of metatarsomere
2 (Fig. 8C). Venter: Prosternal process parabolic, apex with long, tawny setae (Figs. 6E, 9F). Parameres: As in Fig. 10E-F.

Allotype. Female (Fig. 8B). Length $26.0=\mathrm{mm}$; width across humeri $=13.0 \mathrm{~mm}$. As male except in the following respects. Head: Horn absent. Frons and clypeus slightly concave; surface with large, often confluent punctures. Lateral edge of clypeus at anterior edge of ocular canthus sharply elevated into laminate, triangular ridge. Clypeus attenuate, apex narrow (subequal to width of eye), emarginate, with distinct tooth either side of emargination, reflexed (Fig. 8B). Mandibles more exposed. Pronotum: Horn absent. Surface reddish brown, covered by large, dense, round, velutinous punctures; punctures often confluent and with a minute, pale seta at center of each. Anterior margin 

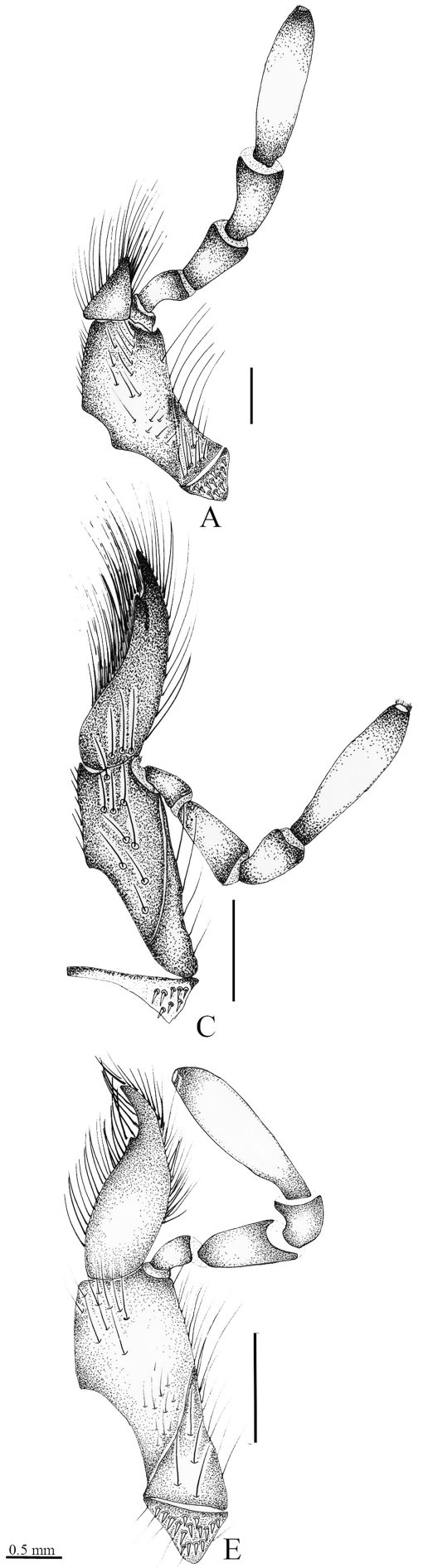

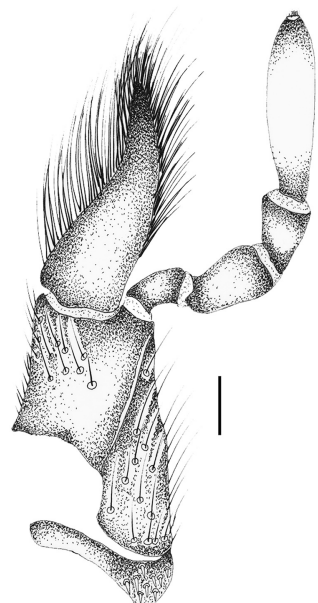

B
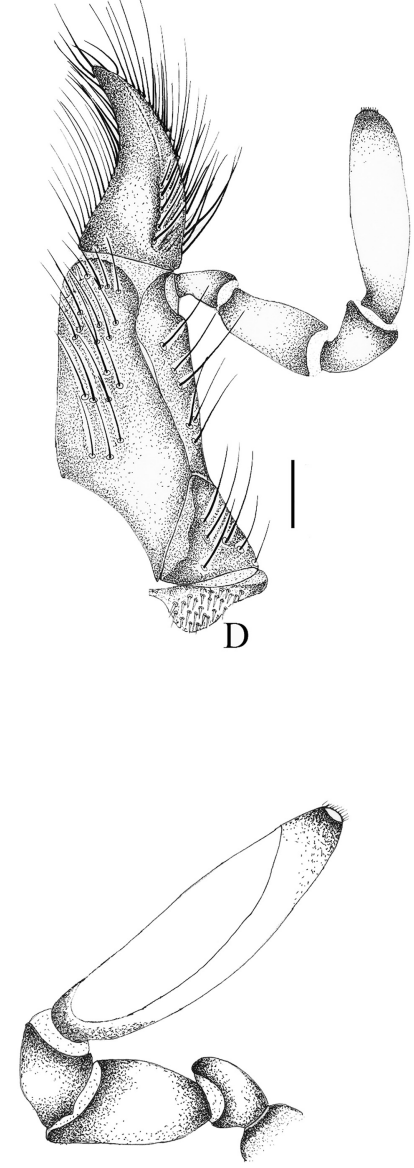

F

Fig. 5. Maxillae, dorsal view. A) Aegopsis curvicornis, B) Brachysiderus quadrimaculatus, C) Lycomedes hirtipes, (D) Mitracephala humboldtii, E) Spodistes grandis Sternberg, F) Apical maxillary palpomere of S. grandis. 

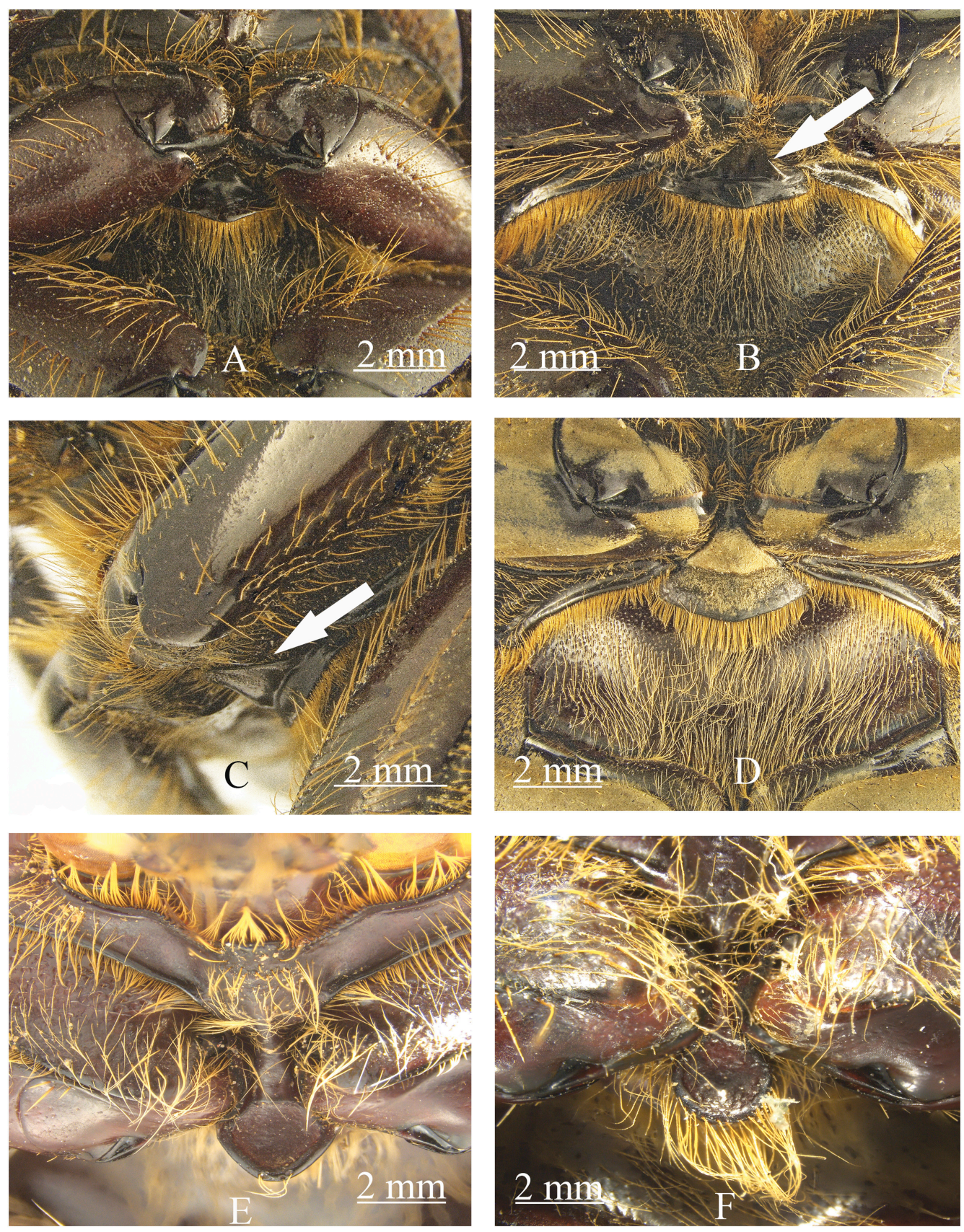

Fig. 6. Prosternal processes. A) Brachysiderus quadrimaculatus, B-C) Mitracephala humboldtii (arrows point to developed processes), D) Spodistes grandis, E) Lycomedes enigmaticus F) L. hirtipes.

at middle tumescent. Pygidium: Surface nearly flat in lateral view. Legs: Protarsus not enlarged, claws subequal in size, not toothed. Median angle at apex of metatibia pronounced, with 2 small spinules.
Etymology. The specific epithet enigmaticus is used here in reference to the rarity of this new species as well as its morphological similarity with Lycomedes hirtipes Arrow. The name is masculine 


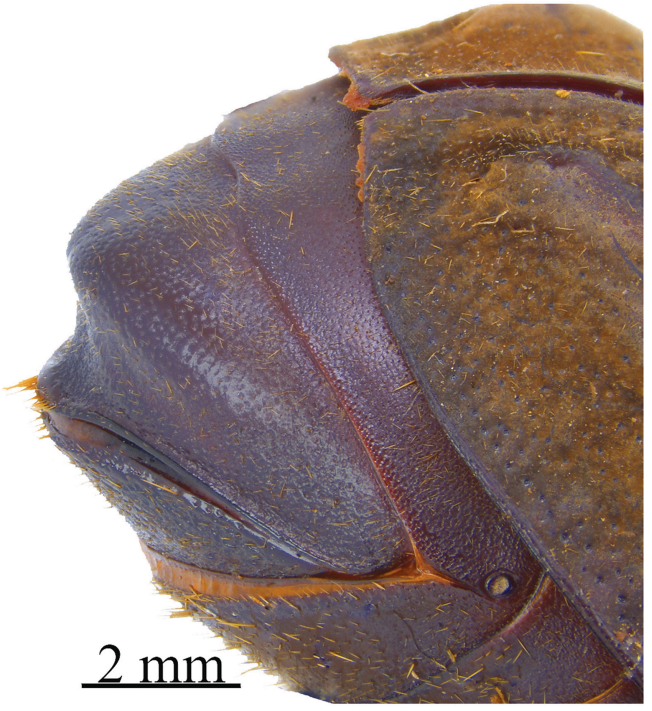

A

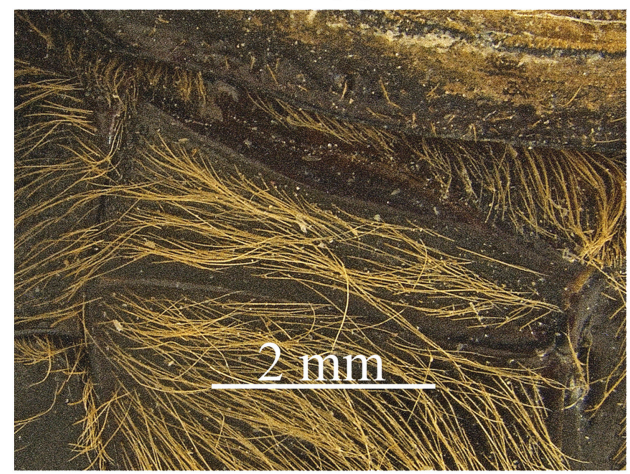

C

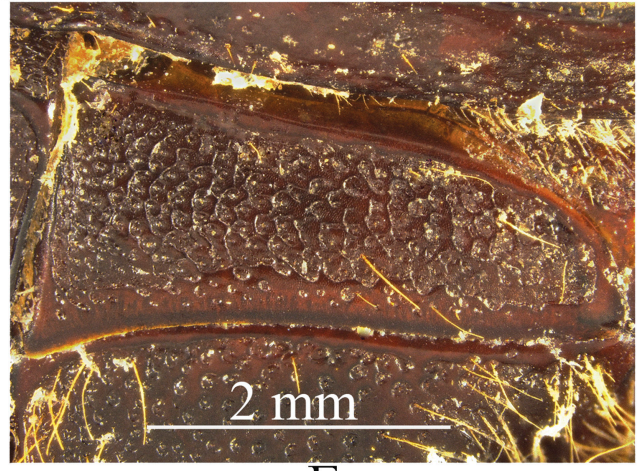

E

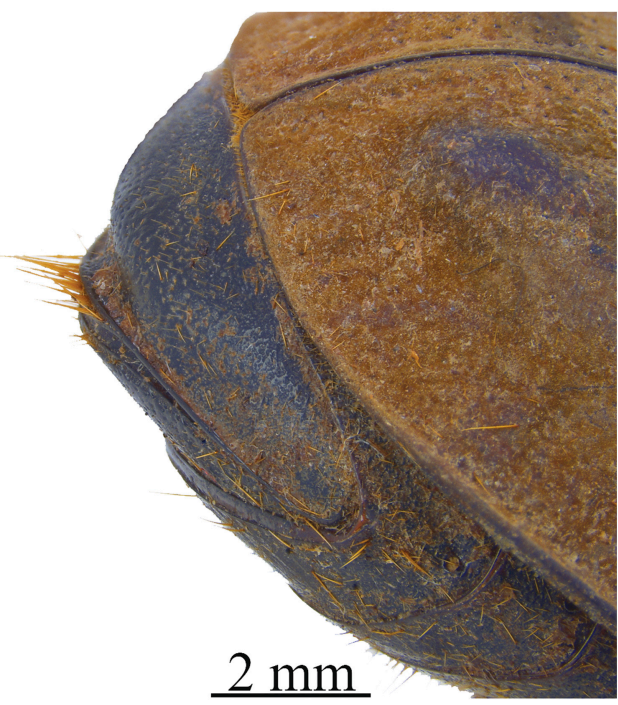

B

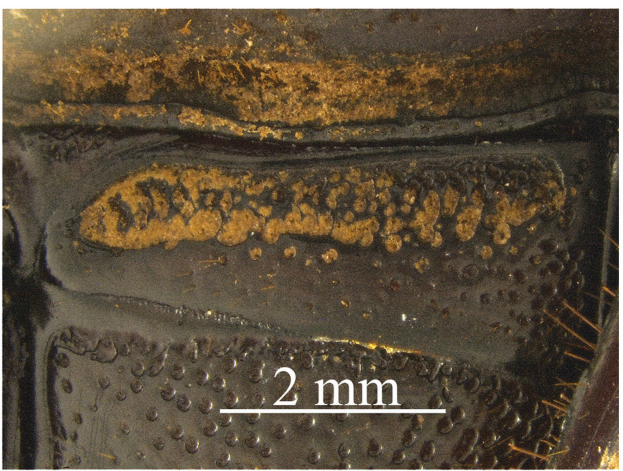

D

Fig. 7. Pygidia: A) Lycomedes reichei, female, dorsolateral view, B) Lycomedes hirtipes, female, dorsolateral view. Metepisterna: C) Lycomedes reichei, D) Horridocalia delislei, E) L. hirtipes. 

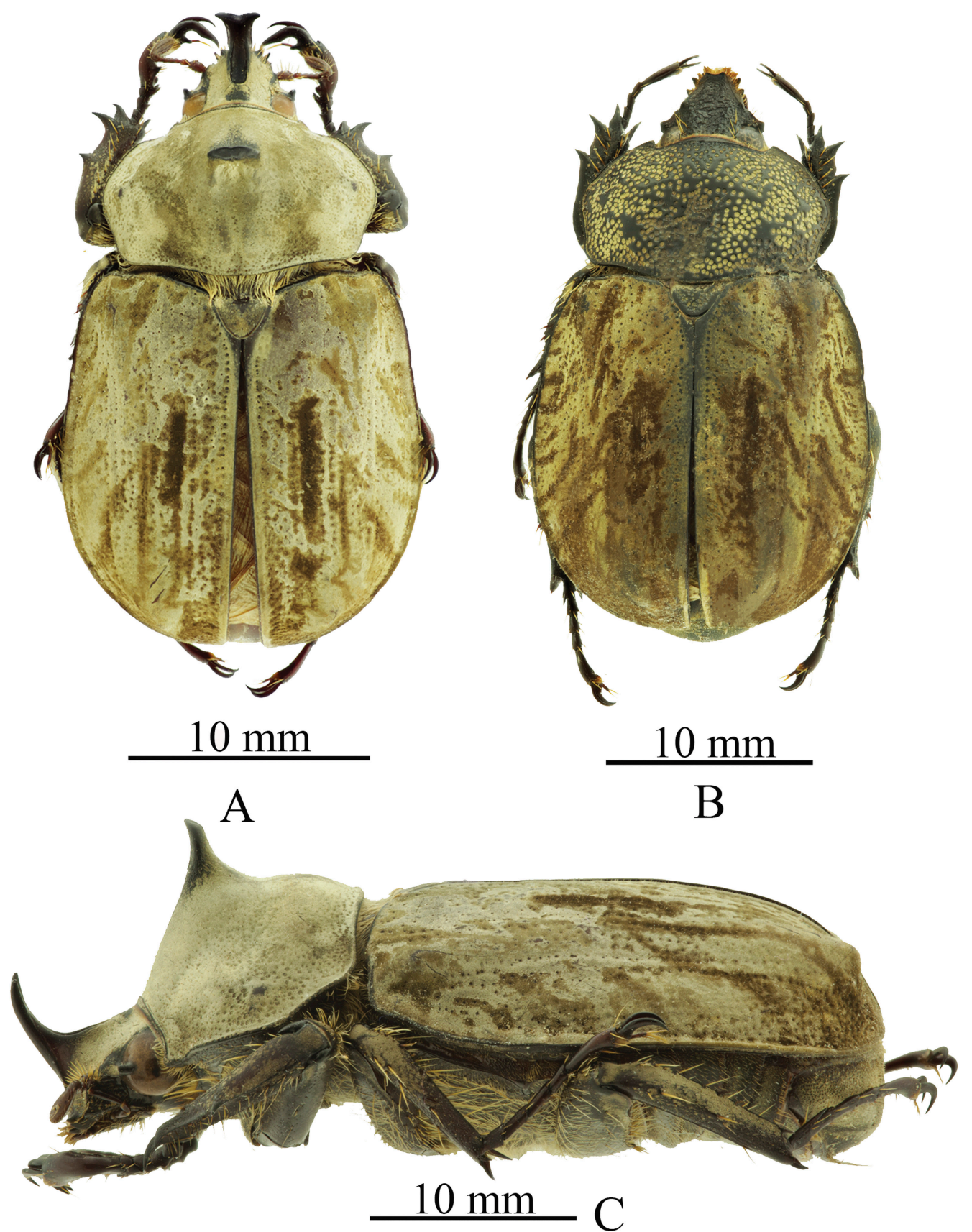

Fig. 8. Lycomedes enigmaticus. A) Male, dorsal view, B) Female, dorsal view, C) Male, lateral view.

to match the gender of the genus, which was named after a mythological king of Troy.

Distribution. Lycomedes enigmaticus is known from Tolima in Colombia (Fig. 12).

Diagnosis. Lycomedes enigmaticus is similar to L. hirtipes, but L. enigmaticus is distinguished by

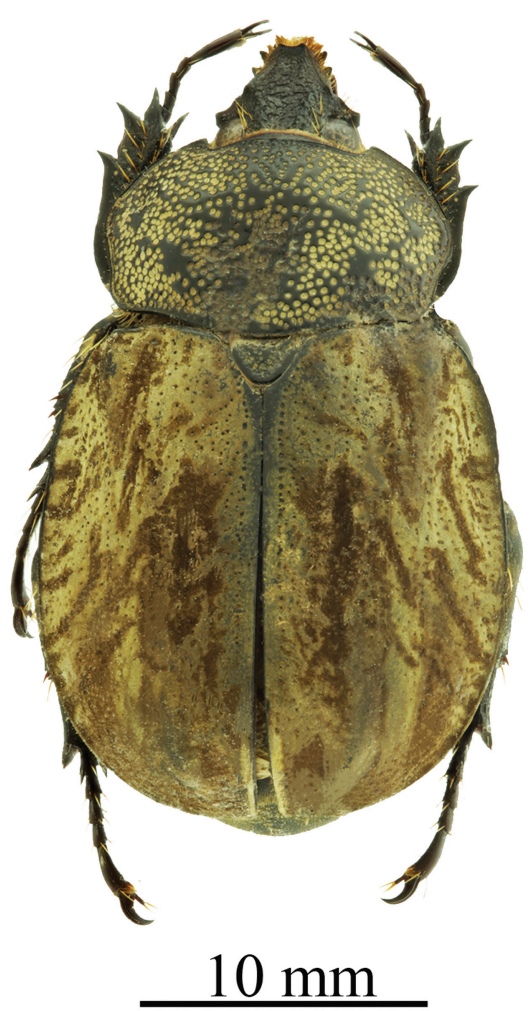

B

the following character combination: male with each side of clypeal apex projecting slightly laterad (Fig. 9D); frons with elongate groove behind horn (groove subtriangular in L. hirtipes (Fig. 9C) or a narrow line as in Lycomedes reichei Brême (Fig. 11A, C)); anterior pronotal margin with a small keel (Fig. 


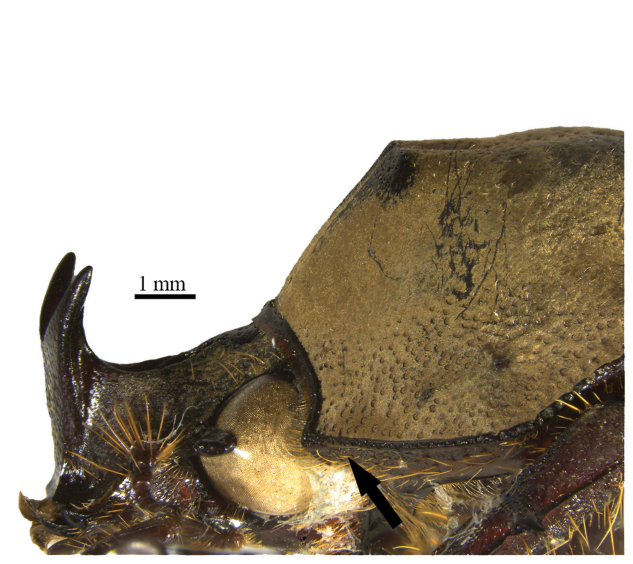

A

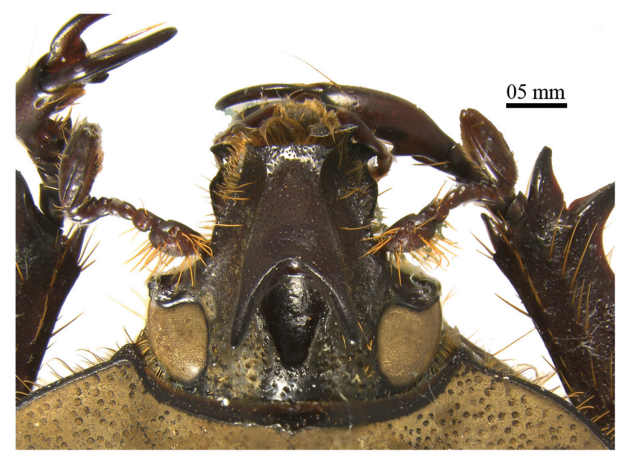

C

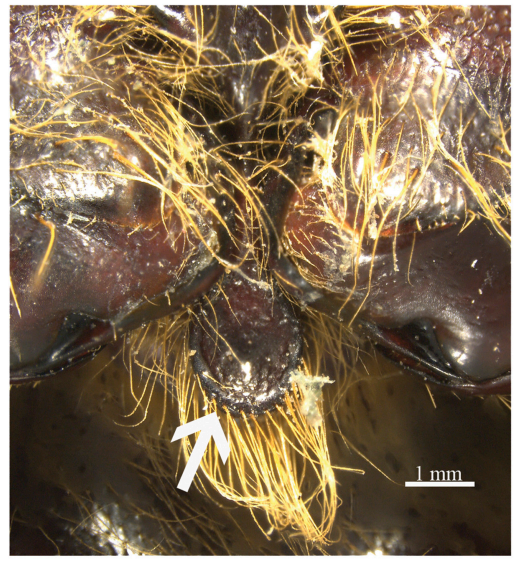

E

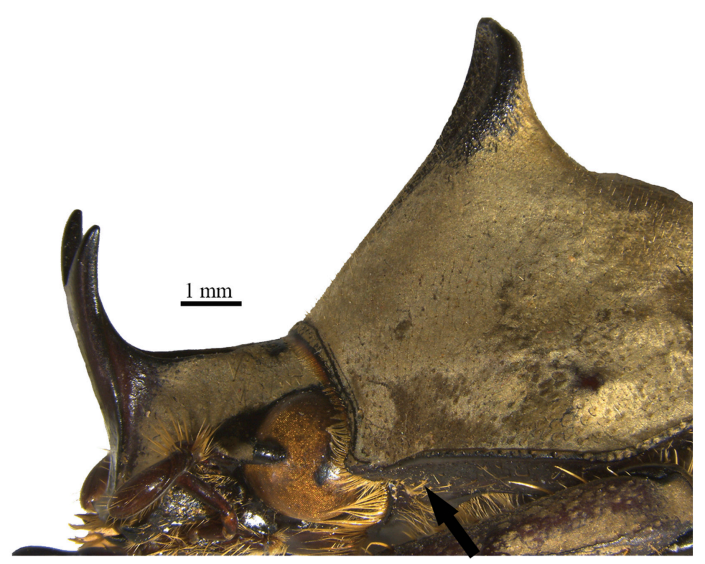

B

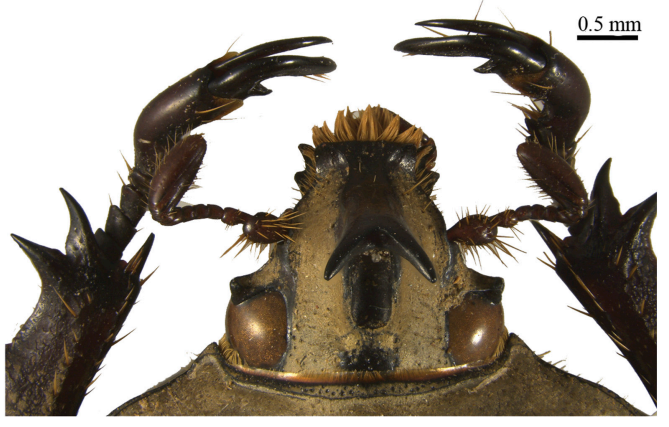

D

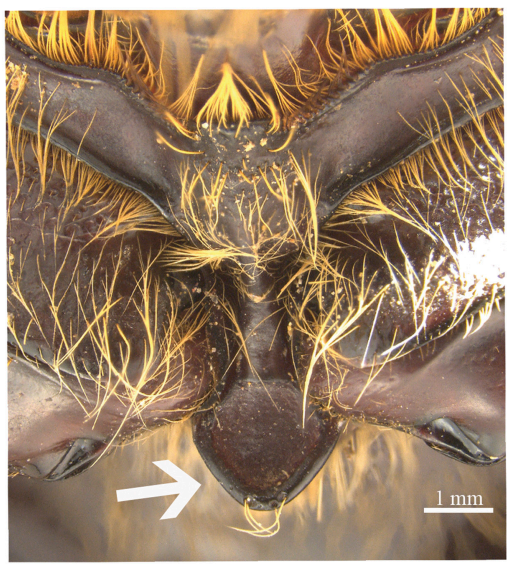

F

Fig. 9. Lycomedes species. L. hirtipes: A) Head and pronotum, lateral view, C) Head showing subtriangular fovea, E) Prosternal process (arrow). L. enigmaticus: B) Head and pronotum, lateral view, D) Head showing elongate fovea, F) Prosternal process (arrow). 


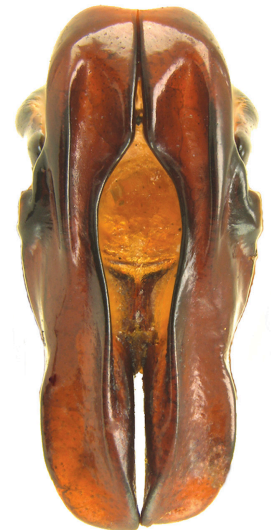

A

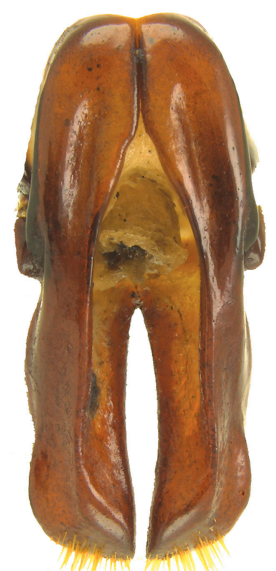

C

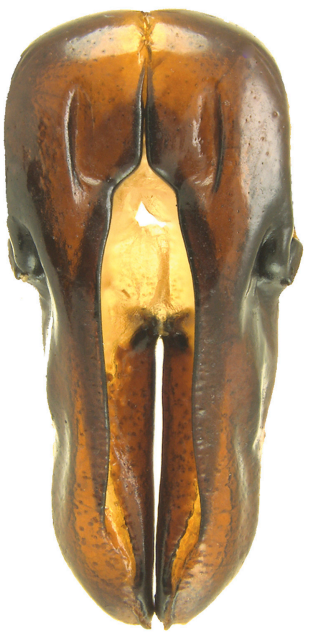

E

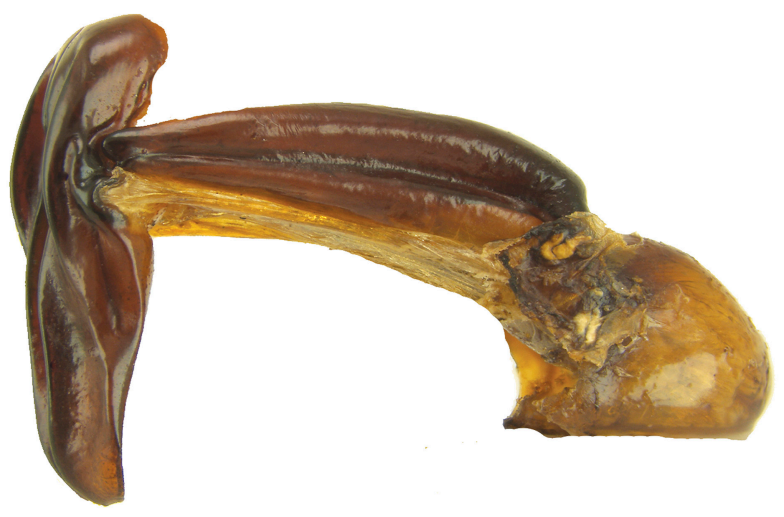

B

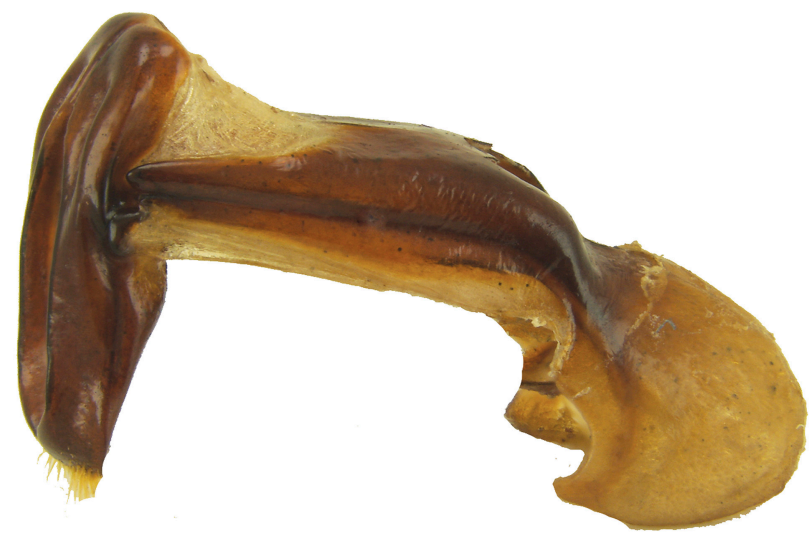

D

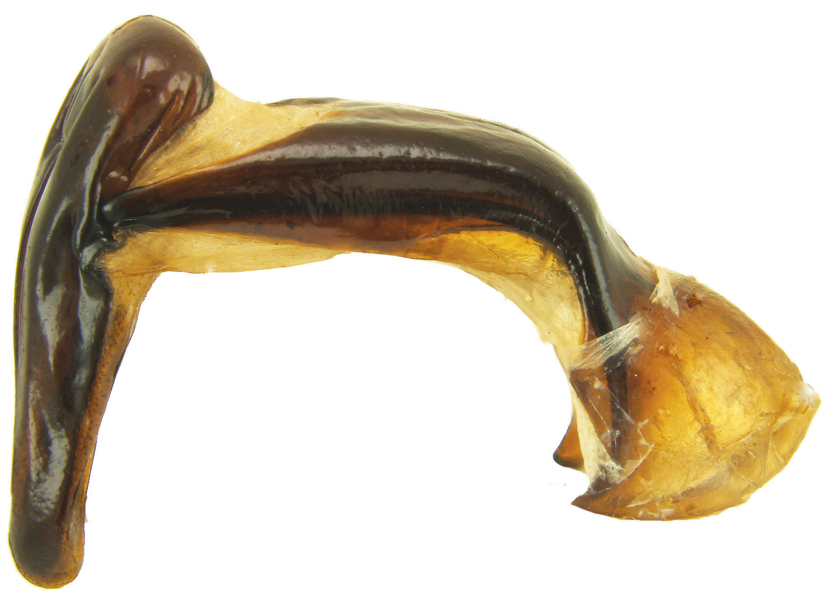

F

Fig. 10. Lycomedes species, parameres. A-B) L. reichei, C-D) L. hirtipes, E-F) L. enigmaticus. 

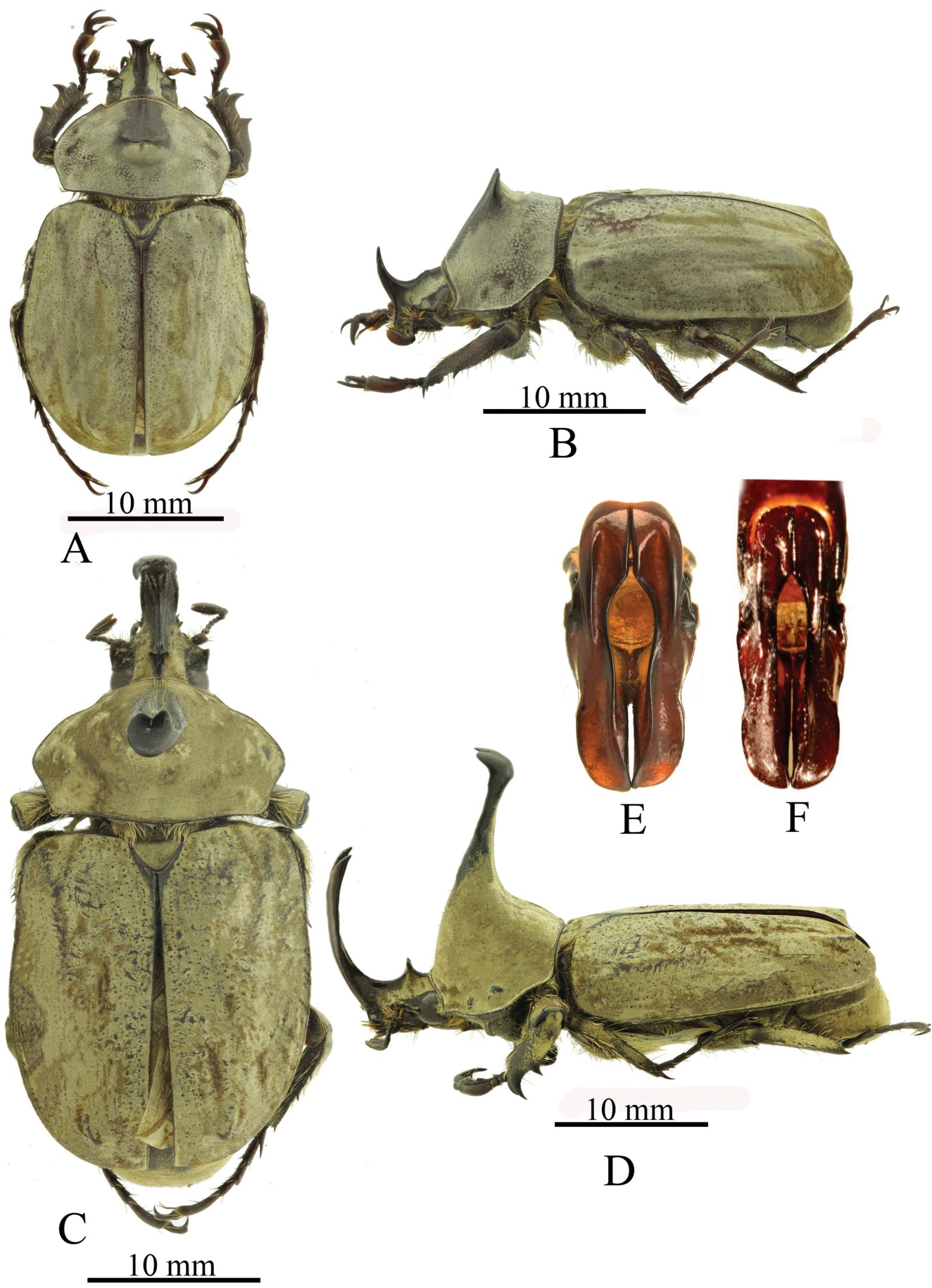

Fig. 11. Lycomedes reichei: A-B) Male minor, dorsal and lateral views, respectively, C-D) Male major, dorsal and lateral views, E) parameres. F) Lycomedes lydiae, parameres. 


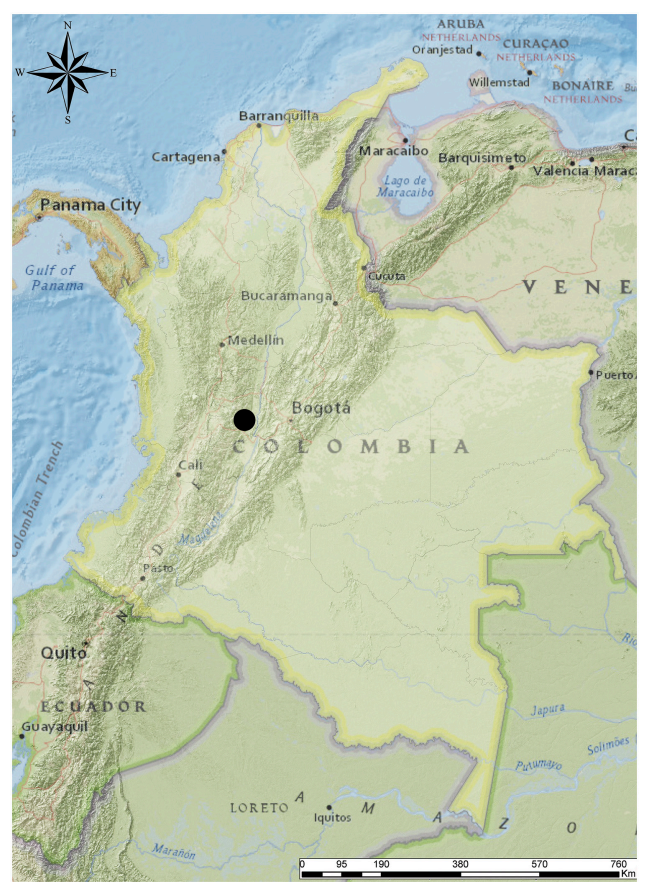

Fig. 12. Location of the type locality of Lycomedes enigmaticus in Colombia.

9B) (keel absent in L. hirtipes and L. reichei (Fig. 9A)); and apex of prosternal process slightly parabolic (Figs. 6E, 9F) (rounded in L. hirtipes (Figs. 6F, $9 \mathrm{E})$ ). The female is similar to other species of Lycomedes, but the prosternal process is similar to the male and different from the processes of $L$. hirtipes and $L$. reichei. Lastly, the form of the parameres is unique (Fig. 10E-F, with the apices lacking setae (compare with L. hirtipes (Fig. 10C-D) and L. reichei (Fig. 10A-B)).

\section{Lycomedes reichei Brême, 1844}

(Figs. 7A, 10A-B, 11A-E)

Lycomedes reichei Brême 1844: 299 (original combination)

Lycomedes lydiae Arnaud 2012: 2 . New synonymy. Specimens $(n=17)$ of $L$. reichei (Fig. 11A-D) from Colombian collections were studied by the first author, and we conclude that $L$. lydiae is conspecific. The parameres of both taxa are similar (compare Fig. 11E vs. Fig. 11F). The two "species" are sympatric, and we believe that $L$. lydiae is simply a variation of the population of L. reichei.

Colombian Distribution. Boyacá, Toguí, En: Pseudotallo de plátano (Musa sp.-Musaceae), 28.ii.1976, R. Vespara, det. as Spodistes sp. by R.
Gordon in 1976 (15 specimens, CTNI-13240. Boyacá, Villa de Leyva, Centro del pueblo, Captyura Manual, $5^{\circ} 37^{\prime} 56.55^{\prime \prime} \mathrm{N}, 73^{\circ} 31^{\prime} 24.08^{\prime \prime} \mathrm{W}$, 2,150 m, 28.xi.2017, J. C. Neita leg. (2 females, IAvH-E-215590 and IAvH-E-215591). Santander, La belleza/Alrede, Casco Urbano/Junio 2004, 2,204 msnm/Cols. Estudiantes G-8vo/Colegio Juan Bosco, /ICN 024097/ Lycomedes reichei Brême 1844. Det. J. C. Neita. 2007 (1 specimen).

\section{Key to the Species of Adult Male LyComedes of Colombia \\ (Modified from Pardo-Locarno et al. 2015)}

1. Cephalic horn trifurcate at apex and with additional tall, erect, bifurcate horn at base. Pronotal horn short, erect. Cundinamarca ....

L. ramosus Arrow

$1^{\prime}$. Cephalic horn bifurcate at ápex ............ 2

2. Cephalic horn longitudinally furrowed on dorsal edge, each side of furrow keel-like....

$2^{\prime}$. Cephalic horn lacking furrow on dorsal edge ........................................ 4

3. Anterior pronotal margin with a small keel. Tolima

L. enigmaticus Neita-Moreno and Ratcliffe, new species

3'. Anterior pronotal margin without a keel. Boyacá, Caldas, Cauca, Huila, Tolima, Huila, Valle L. hirtipes Arrow

4. Frons with central longitudinal furrow narrow, shallow. Boyacá and Santander

L. reichei Brême

4'. Frons lacking central furrow, instead with a rounded dilation ............................. 5

5. Pronotum completely covered with large, irregular punctures, some coalescent. Cephalic horn at base expanded laterally on each side into subtriangular projection. Santander

\section{L. salazari Pardo-Locarno,}

Villalobos-Moreno, and Stechauner

5'. Pronotum with small, sparse punctures. Cephalic horn at base lacking subtriangular projection. Antioquia L. burmeisteri Waterhouse

\section{Key to the Species of Adult Female LyCOMEDES OF COLOMbia}

(Modified from Pardo-Locarno et al. 2015)

(Females of L. ramosus Arrow are unknown or unavailable.)

1. Clypeus short, width at base of ocular canthi nearly twice as wide as long, apex slightly narrowed ....

L. salazari Pardo-Locarno,

Villalobos-Moreno, and Stechauner

1'. Clypeus long, narrower at base, markedly narrowed towards apex 
2. Head broadly, shallowly depressed along middle

$2^{\prime}$. Head not depressed along middle

\section{L. burmeisteri Waterhouse}

3. Pygidium strongly protuberant at middle and strongly concave on apical half (Fig. 7A) ....

L. reichei Brême

3'. Pygidium convex at middle, not strongly protuberant, apical third concave (Fig. 7B) ......... 4

4. Clypeal apex broad. Prosternal process short (Fig. 6E)

L. enigmaticus Neita-Moreno and Ratcliffe, new species

4'. Clypeal apex narrow. Prosternal process moderately long (Fig. 6F)

L. hirtipes Arrow

\section{ACKnowledgments}

We thank Nelson Canal and Nataly Forero (Universidad del Tolima in Colombia) for the loan of specimens of L. enigmaticus. German Amat (Instituto de Ciencias Naturales, Universidad Nacional de Colombia, sede Bogotá) provided some specimens of L. reichei from Santander. Stephane Le Tirant and R. Limoges (Insectarium de Montréal, QC, Canada) are gratefully acknowledged for providing images of Brachysiderus quadrimaculatus Waterhouse (male), Horridocalia delislei Endrödi (male), and Mitracephala humboldtii Thomson (female). We thank Kevin Borja (Instituto Alexander von Humboldt, Colombia) for providing the distribution map. This work was funded primarily by the Instituto Alexander von Humboldt, Colombia.

\section{References Cited}

Arnaud, P. 2012. Une nouvelle espèce de Lycomedes. Besoiro 21: 2-3.

Endrödi, S. 1970. Monographie der Dynastinae (Coleoptera). 3. Tribus: Agaocephalini. Acta Zoologica Academiae Scientiarum Hungaricae 16(1-2): 27-96.

Endrödi, S. 1985. The Dynastinae of the World. Dr. W. Junk Publisher, Dordrecht, The Netherlands.

Environmental Systems Research Institute. 2013. ArcGis 10.2. Inc., Redlands, CA.

Gasca-Álvarez, H. J., and G. Amat-García. 2010. Synopsis and key to the genera of Dynastinae (Coleoptera, Scarabaeoidea, Scarabaeidae) of Colombia. ZooKeys 34: 153-192.
Krajcik, M. 2005. Dynastinae of the World Checklist (Coleoptera: Scarabaeidae: Dynastinae). Animma.X, Supplement No. 2: 1-122.

Milani, L. 2017. Sinopsi del genere Lycomedes Breme (Coleoptera, Scarabaeidae, Dynastinae, Agaocephalini) con ridescrizione de Lycomedes ohausi Arrow maschio, descrizione de Lycomedes ohausi femmina e di una nuova specie dall'Ecuador. Giornale Italiano de Entomologia 14: 755-774.

Neita-Moreno, J. C. 2015. Revisión del género Colacus Ohaus (Coleoptera: Scarabaeidae: Dynastinae: Agaocephalini). Dugesiana 22: 187-199.

Neita-Moreno, J. C., and A. Gaigl. 2008. Escarabajos de Importancia Agrícola en Colombia (Coleoptera: Scarabaeidae "Pleurosticti"). Produmedios, Universidad Nacional de Colombia, Bogotá, Colombia.

Neita-Moreno, J. C., M. de Oliveira, and M. A. Morón. 2014. Larval and pupal descriptions of two Aegopsis species (Coleoptera: Melolonthidae: Dynastinae). Florida Entomologist 97: 114-125.

Oliveira, C. M., M. A. Morón, and M. R. Frizzas. 2008. Aegopsis bolboceridus (Coleoptera: Melolonthidae): An important pest on vegetables and corn in central Brazil. Florida Entomologist 91: 324-327.

Pardo-Locarno, L. C., and M. A. Morón. 2006. Description of the third instar larva and pupa of Lycomedes hirtipes Arrow (Coleoptera: Dynastinae: Agaocephalini) with notes on its biology and distribution in Colombia. Proceedings of the Entomological Society of Washington 108(3): 661-671.

Pardo-Locarno, L. C., A. Villalobos-Moreno, and R. Stechauner. 2015. Nueva especie de Lycomedes Brème, 1844 (Coleoptera: Melolonthidae: Dynastinae) de los Andes colombianos y clave para identificación de las especies. Insecta Mundi 0455: 1-14.

Ratcliffe, B. C. 2003. The dynastine scarab beetles of Costa Rica and Panama (Coleoptera: Scarabaeidae: Dynastinae). Bulletin of the University of Nebraska State Museum 16: 1-506.

Ratcliffe, B. C., and R. D. Cave. 2015. The dynastine scarab beetles of the West Indies (Coleoptera: Scarabaeidae: Dynastinae). Bulletin of the University of Nebraska State Museum 28: 1-346.

Restrepo-Giraldo, H., M. A. Morón, F. Vallejo, L. C. Pardo-Locarno, and A. López-Avila. 2003. Catálogo de Coleoptera Melolonthidae (Scarabaeidae Pleurosticti) de Colombia. Folia Entomológica Mexicana 42: 239-263.

(Received 19 April 2019; accepted 19 October 2019. Publication date 19 December 2019.) 